\title{
Carbohydrate Degradation Pathways in Thiobacillus A2 Grown on Various Sugars
}

\author{
By ANN P. WOOD AND DON P. KELLY* \\ Department of Environmental Sciences, University of Warwick, Coventry CV4 $7 A L$
}

(Received 22 February 1980)

\begin{abstract}
A detailed radiorespirometric and enzymological analysis was made of the wild-type and GFI strains of Thiobacillus A2 grown on numerous sugars. The wild-type used the EmbdenMeyerhof, Entner-Doudoroff and pentose phosphate pathways for glucose oxidation only after culture on glucose. The fast-growing strain GFI used all three pathways after growth on glucose, maltose or fructose. The wild-type grown on a wide range of pentoses, hexoses, disaccharides, a trisaccharide and a mixture of glucose and maltose oxidized glucose by means of the Entner-Doudoroff pathway (68 to 90\%) and pentose phosphate pathway $(10$ to $32 \%)$. The key enzyme determining the presence or absence of the Embden-Meyerhof pathway was 6-phosphofructokinase. Other mechanisms, such as a phosphoketolase pathway, were shown to be unimportant, even during growth on pentoses. Arabinose was metabolized via hexose phosphate synthesis. The mechanisms of regulation of sugar metabolism and the energetic significance of alternative pathways are discussed.
\end{abstract}

\section{INTRODUCTION}

Thiobacillus A2 is a facultative autotroph capable of heterotrophic growth on a wide range of organic compounds including numerous mono-, di- and trisaccharides (Taylor \& Hoare, 1969; Wood \& Kelly, 1977). It exhibits some unusual features in its growth on and metabolism of sugars. Disaccharides, such as sucrose and maltose, on which it grows rapidly (Wood \& Kelly, 1977) stimulate its slow growth on glucose. Cultures grown on glucose exhibited the concerted operation of the Embden-Meyerhof (EM), EntnerDoudoroff (ED) and pentose phosphate (PP) pathways (Wood et al., 1977; Wood \& Kelly, 1978, 1979).

The operation of all three catabolic pathways for glucose was observed only under some growth conditions; the EM pathway was not found in some chemostat cultures of the wildtype strain grown on glucose (Wood \& Kelly, 1979) and only the ED and PP pathways appeared to function in chemostat cultures grown mixotrophically on glucose and thiosulphate (Smith et al., 1980) or on succinate and glucose (Wood \& Kelly, 1980). With the elimination of phosphofructokinase, and hence of the EM pathway, the organism thus became metabolically more similar to the Pseudomonas species, which typically lack EM pathway activity (Wang et al., 1959; Stern et al., 1960; Tiwari \& Campbell, 1969; Ornston, 1971). A chance observation that a culture of Thiobacillus A2 grown on sucrose appeared to lack the EM pathway when tested radiorespirometrically (A. P. Wood, unpublished) and the observation that the growth substrate and prior culture history markedly influenced the metabolic pattern of the organism (Smith et al., 1980; Wood \& Kelly, 1980) led us to examine the enzymic composition and radiorespirometric behaviour of the wild-type and fast-growing GFI strain of Thiobacillus A2 after batch culture on a wide range of sugars. These observations serve to demonstrate that no particular significance can be attributed to 
the presence or absence of a functional EM pathway during growth of the organism on glucose-containing media, but do enable a number of deductions concerning regulatory mechanisms for sugar metabolism by Thiobacillus A2.

\section{METHODS}

Abbreviations. The following abbreviations are used: KDPG, 6-phospho-2-keto-3-deoxy-D-gluconate; 6-PG, 6-phosphogluconate; PEP, phosphoenolpyruvate; FDP, fructose 1,6-bisphosphate; PFK, phosphofructokinase; EM, Embden-Meyerhof; ED, Entner-Doudoroff; PP, pentose phosphate.

Organisms and growth media. Wild-type Thiobacillus A2 and the fast-growing strain GFI derived from it were used as described previously (Wood \& Kelly, 1977). Cultures of both organisms were grown to the late-exponential stage of growth on sugars at concentrations as stated in the text. Routinely, Thiobacillus A2 cultures were inoculated from thiosulphate-agar slants. Cultures on mannose, xylose and ribose were previously subcultured on the sugars two, four and four times, respectively, before use in radiorespirometry. Cultures of strain GFI, normally maintained on glucose slopes (Wood \& Kelly, 1977), were subcultured two, three and four times, respectively, on maltose, fructose and arabinose before use in radiorespirometry; each was subcultured twice before use in enzyme assays.

Preparation of cell-free extracts and assay of enzymes. Preparation of French press extracts and most assays have been described previously (Wood et al., 1977). The combined activities of 6-phosphogluconate dehydratase and KDPG aldolase were assayed using the coupled assay with 5 mM-6-PG as substrate (Wood et al., 1977). KDPG aldolase was also assayed directly using KDPG (1 or $2 \mathrm{mM}$ ) as substrate. In most cases, pyruvate production was more rapid from KDPG than from 6-PG, indicating the 6-PG dehydratase to be rate-limiting in the coupled assay. Phosphoketolase [EC 4.1.2.9; D-xylulose-5-phosphate D-glyceraldehyde3-phosphate lyase (phosphate acetylating)] was assayed by the method of Goldberg et al. (1966) at $30^{\circ} \mathrm{C}$ for 15 min, measuring the amount of glyceraldehyde 3-phosphate liberated by enzymic cleavage of xylulose-5phosphate (5 or $20 \mathrm{~mm}$ ). Fructose-1,6-bisphosphatase (EC 3.1.3.11; D-fructose-1,6-bisphosphate 1phosphohydrolase) was assayed by the method of Johnson \& MacElroy (1973).

Radiorespirometry. Radiorespirometry methods and substrates, collection and measurement of ${ }^{14} \mathrm{CO}_{2}$, and materials have been described previously (Wood et al., 1977). All radiochemicals were from The Radiochemical Centre, Amersham or New England Nuclear, Germany.

Chemicals. $\left[3-{ }^{14} \mathrm{C}\right]$ Glucose (New England Nuclear) was a generous gift from $\mathrm{Dr}$ C. H. Wang. Barium KDPG was kindly provided by Professor J. R. Quayle. It contained $1178 \mu \mathrm{mol} \mathrm{KDPG}$ and $130 \mu \mathrm{mol}$ 6-PG per $\mathrm{g}$, indicating a purity of about $54 \%(\mathrm{w} / \mathrm{w})$. Prior to use, barium was removed by treatment in aqueous solution with Dowex 50W-X8(H+ $\left.\mathrm{H}^{+}\right)$resin and the solution was adjusted to $\mathrm{pH} 6.95$ with $\mathrm{NaOH}$. Xylulose 5 -phosphate (approximately $65 \%$ purity) was from Sigma. Commercially produced sugars of the highest purity available were used as growth substrates. Maltose ( $>99 \%$ pure), xylose, galactose, arabinose $(96 \%$ pure) and melezitose were from Sigma; other sugars were from BDH or Fisons.

\section{RESULTS}

Radiorespirometric patterns of glucose oxidation by wild-type Thiobacillus A2 grown on various sugars

After growth in batch culture on glucose using a sucrose-grown inoculum taken from a thiosulphate stock culture (as described previously by Wood \& Kelly, 1977; Wood et al., 1977), ${ }^{14} \mathrm{CO}_{2}$ release from specifically labelled glucoses by Thiobacillus A2 (Fig. 1 a) indicated the triple pathway mechanism for glucose oxidation previously reported, i.e. ${ }^{14} \mathrm{CO}_{2}$ production rates from C-3 and C-4 exceeding those from C-1 (Wood et al., 1977; Wood \& Kelly, $1978,1979)$. After growth on glucose using an inoculum taken directly from thiosulphateagar slopes, markedly more $\mathrm{C}-1$ release and more variable $\mathrm{C}-3$ release from glucose occurred, indicating that the Entner-Doudoroff and pentose phosphate pathways are more important during glucose oxidation by bacteria cultured in this way (Fig. $1 b$; Table 1 ). After growth on maltose, glucose radiorespirometric kinetics indicated only the ED and PP pathways to be operative (Fig. $2 a$; Table 1 ) since only C-1 and C-4 release were high, C-1 cumulatively exceeding C-4, while C-3 release was similar to, or lower than, that of C-6. This contrasted with the behaviour of the fast-growing strain GFI, which retained EM 

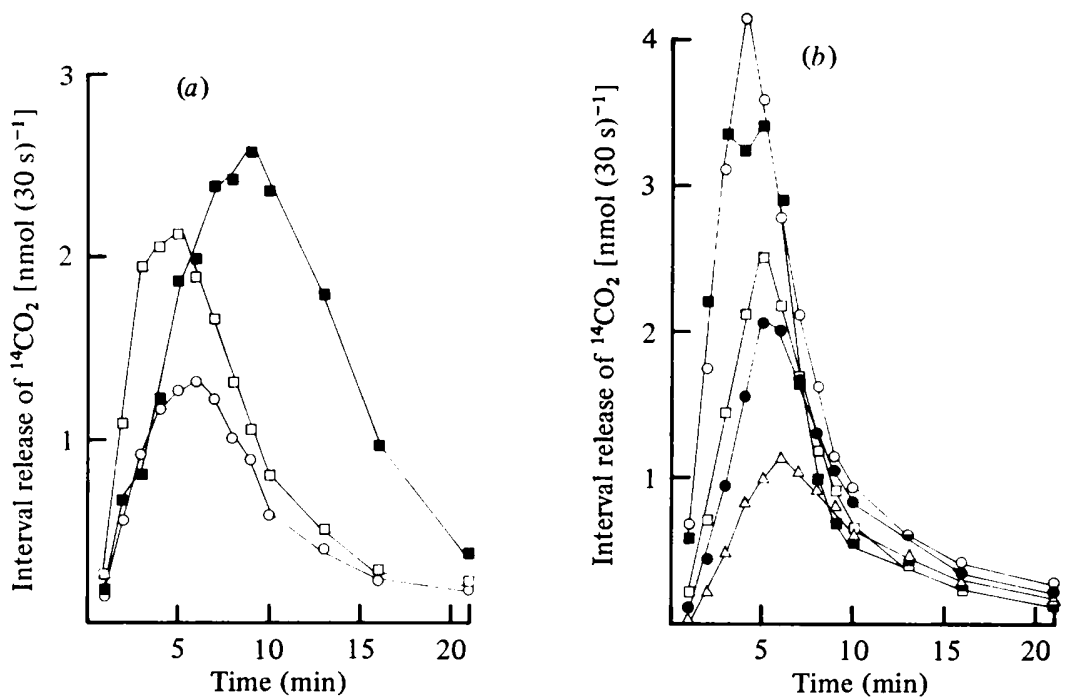

Fig. 1. Radiorespirometry of specifically labelled $\left[{ }^{14} \mathrm{C}\right]$ glucoses by Thiobacillus A2 grown on glucose from inoculum cultures grown on $(a)$ sucrose and $(b)$ thiosulphate. Release of ${ }^{14} \mathrm{CO}_{2}$ from glucose labelled in C-1 $(\bigcirc)$, C-2 $(O), C-3(\square), C-4(\square)$ and C-6 $(\triangle)$ is expressed as interval release $\left[\mathrm{nmol}(30 \mathrm{~s})^{-1}\right.$ ] from $66.6 \mathrm{nmol}$ glucose by $(a) 1.31 \mathrm{mg}$ dry wt and $(b) 1.75 \mathrm{mg}$ dry wt Thiobacillus A2.

Table 1. Cumulative release of ${ }^{14} \mathrm{CO}_{2}$ from specifically labelled $\left[{ }^{14} \mathrm{C}\right]$ glucoses under standard radiorespirometric assay conditions by Thiobacillus A2 grown on different sugars

\begin{tabular}{|c|c|c|c|c|c|c|c|c|}
\hline \multirow{2}{*}{$\begin{array}{l}\text { Growth substrate } \\
\quad(\text { concn, } \mathrm{mm})\end{array}$} & \multirow{2}{*}{$\begin{array}{l}\text { Amount of } \\
\text { organism } \\
\text { used } \\
\text { [mg dry wt } \\
\left(2 \mathrm{ml}^{-1}\right]\end{array}$} & \multirow{2}{*}{$\begin{array}{c}\text { Incubation } \\
\text { time } \\
\text { (min) }\end{array}$} & \multicolumn{5}{|c|}{$\begin{array}{c}{ }^{14} \mathrm{CO}_{2} \text { release } \\
\text { (nmol, from } 66 \cdot 6 \mathrm{nmol} \text { glucose) }\end{array}$} & \multirow{2}{*}{$\begin{array}{l}\text { Rate of } \\
\text { oxidation } \\
\text { of }\left[\mathrm{U}^{14} \mathrm{C}\right]- \\
\text { glucose }^{*}\end{array}$} \\
\hline & & & C-1 & $\mathrm{C}-2$ & $\mathrm{C}-3$ & $\mathrm{C}-4$ & C-6 & \\
\hline $\begin{array}{l}\text { Glucose (20) } \\
\text { (sucrose inoculum) }\end{array}$ & $1 \cdot 75$ & 31 & $26 \cdot 7$ & $25 \cdot 4$ & $34 \cdot 2$ & $51 \cdot 2$ & $16 \cdot 3$ & $11 \cdot 2$ \\
\hline $\begin{array}{l}\text { Glucose (20) } \\
\text { (thiosulphate inoculum) }\end{array}$ & $1 \cdot 75$ & 31 & $\begin{array}{l}\dagger(1) 53.6 \\
\dagger(2) 57.9\end{array}$ & $\begin{array}{l}33 \cdot 0 \\
33 \cdot 0\end{array}$ & $\begin{array}{l}32 \cdot 3 \\
19 \cdot 2\end{array}$ & $\begin{array}{l}43 \cdot 7 \\
43 \cdot 7\end{array}$ & $\begin{array}{l}20 \cdot 2 \\
16 \cdot 0\end{array}$ & $9 \cdot 9$ \\
\hline Maltose (10) & 1.68 & 31 & $54 \cdot 8$ & $25 \cdot 3$ & $21 \cdot 3$ & $44 \cdot 2$ & $22 \cdot 3$ & $9 \cdot 0$ \\
\hline Glucose (16) + Maltose (2) & 1.83 & 31 & $48 \cdot 9$ & $21 \cdot 9$ & $20 \cdot 1$ & $36 \cdot 6$ & $19 \cdot 4$ & $6 \cdot 8$ \\
\hline Sucrose (10) & $1 \cdot 74$ & 31 & $52 \cdot 5$ & $25 \cdot 2$ & $16 \cdot 7$ & $30 \cdot 7$ & $27 \cdot 2$ & $7 \cdot 2$ \\
\hline Fructose (20) & $4 \cdot 50$ & 140 & $48 \cdot 7$ & $27 \cdot 7$ & $20 \cdot 9$ & $33 \cdot 6$ & $16 \cdot 0$ & $0 \cdot 7$ \\
\hline Galactose (20) & 1.82 & 31 & $51 \cdot 6$ & $20 \cdot 5$ & $17 \cdot 0$ & $35 \cdot 7$ & $14 \cdot 9$ & $6 \cdot 9$ \\
\hline Mannose (20) & $1 \cdot 72$ & 31 & $34 \cdot 6$ & $17 \cdot 2$ & $13 \cdot 0$ & $22 \cdot 9$ & $16 \cdot 1$ & $2 \cdot 5$ \\
\hline Melezitose (8) & $1 \cdot 82$ & 31 & $48 \cdot 1$ & $17 \cdot 2$ & $17 \cdot 9$ & $26 \cdot 6$ & $15 \cdot 9$ & $6 \cdot 0$ \\
\hline Arabinose (24) & 1.76 & 31 & $46 \cdot 8$ & $22 \cdot 0$ & $17 \cdot 8$ & $40 \cdot 1$ & $12 \cdot 0$ & $11 \cdot 1$ \\
\hline Ribose (24) & $5 \cdot 63$ & 90 & $48 \cdot 2$ & $30 \cdot 6$ & $20 \cdot 4$ & $39 \cdot 0$ & $16 \cdot 9$ & 0.7 \\
\hline Xylose (24) & $1 \cdot 80$ & 31 & $54 \cdot 4$ & $20 \cdot 3$ & $15 \cdot 7$ & $39 \cdot 7$ & $12 \cdot 1$ & $13 \cdot 4$ \\
\hline
\end{tabular}

* Expressed as $\mathrm{nmol}{ }^{14} \mathrm{CO}_{2} \mathrm{~min}^{-1}(\mathrm{mg} \text { dry } \mathrm{wt})^{-1}$. $\dagger$ Results from two separate experiments.

pathway activity after growth on maltose (Fig. $2 b$ ). Similarly, after growth on fructose, wild-type Thiobacillus A2 lost EM pathway activity and oxidized glucose very slowly (Fig. $3 a$ ), but strain GFI retained all three pathways (Fig. 3b). Wild-type Thiobacillus A2 did not exhibit significant EM pathway activity when assayed radiorespirometrically after growth on any other sugar tested, including a mixture of $16 \mathrm{~mm}$-glucose and $2 \mathrm{~mm}$ maltose (Table 1), on which fast growth with simultaneous use of the sugars occurs (Wood \& Kelly, 1977).

Cumulative ${ }^{14} \mathrm{CO}_{2}$ release from glucose by these various cultures (Table 1) was used to 


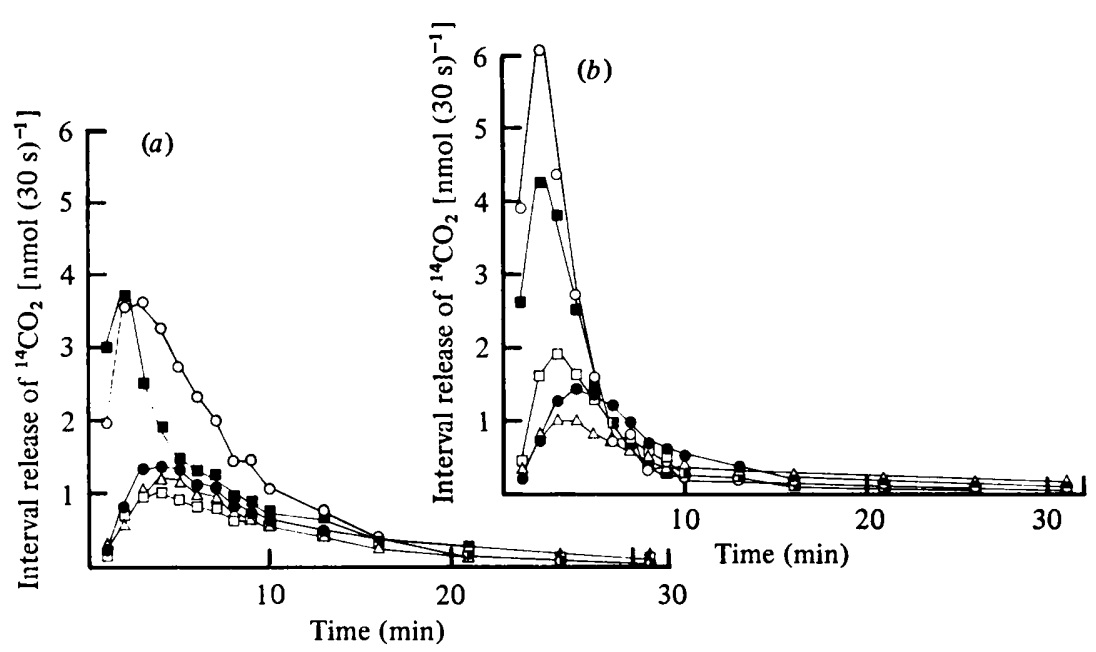

Fig. 2. Radiorespirometry of specifically labelled $\left[{ }^{14} \mathrm{C}\right]$ glucoses by Thiobacillus $\mathrm{A} 2$ grown on maltose: (a) wild-type $\left(1.68 \mathrm{mg}\right.$ dry wt) and $(b)$ strain GFI $\left(1.80 \mathrm{mg}\right.$ dry wt). Release of ${ }^{14} \mathrm{CO}_{2}$ from glucose labelled in C-1 $(\bigcirc)$, C-2 $(\odot)$, C-3 $(\square)$, C-4 $(\square)$ and C-6 $(\triangle)$ is expressed as interval release from $66.6 \mathrm{nmol}$ glucose.

calculate the relative contributions of the ED and PP pathways (Table 2) using the dualpathway equation (Wood \& Kelly, 1979): the fraction of glucose metabolized by the PP pathway is given by $\mathrm{PP}=[(\mathrm{C}-1)-(\mathrm{C}-4)] /[$ total glucose $(\mathrm{nmol})]$ and that metabolized by the ED pathway is given by ED $=1-\mathrm{PP}$, where $(\mathrm{C}-1)$ and $(\mathrm{C}-4)$ indicate the total ${ }^{14} \mathrm{CO}_{2}$ output (nmol) from $\left[1-{ }^{14} \mathrm{C}\right]$ glucose and $\left[4-{ }^{14} \mathrm{C}\right]$ glucose, respectively. Where three pathways were indicated, they were calculated according to Wood et al. (1977), although this probably overestimated the EM pathway to some extent (Wood \& Kelly, 1979, 1980). In cultures lacking the EM pathway, the ED pathway contributed 70 to $90 \%$ of the observed glucose oxidation. Absolute rates of glucose oxidation (Table 1) were significantly depressed only in cultures grown on fructose, ribose and mannose, while all others, including chemostat cultures (Wood \& Kelly, 1979, 1980), showed rates of 11.2 ( \pm S.D. 3.9) $\mathrm{nmol} \mathrm{CO}_{2} \mathrm{~min}^{-1}$ (mg dry wt) $)^{-1}$ (28 determinations).

\section{Enzymes of carbohydrate metabolism in Thiobacillus A2 grown on various sugars}

Significant phosphofructokinase activity, essential to the EM pathway, was found (Table 3) only in cultures grown on glucose, confirming the virtual absence of this pathway under other growth conditions. KDPG aldolase was present at high activity in all cases, but 6-phosphogluconate dehydratase, the other enzyme essential to the ED pathway, varied greatly in response to the growth substrate (Table 3 ) when determined in the coupled assay with KDPG aldolase. This enzyme has previously been identified as potentially a regulatory locus in sugar metabolism by Thiobacillus A2 (Wood \& Kelly, 1980), but in these experiments low 6-PG dehydratase was not accompanied by any decrease in apparent overall ED pathway activity (Tables 2 and 3). A possible alternative route to the ED pathway for C-1 and C-4 release from glucose is via the phosphoketolase reaction (Greenley \& Smith, 1979; Wood \& Kelly, 1979), but this enzyme was active only at low levels in any of our present cultures (Table 3). FDP aldolase and glucosephosphate isomerase were not indicated to be rate-limiting or key regulatory enzymes (Table 3 ).

\section{Effect of growth substrate on sugar metabolism by strain GFI of Thiobacillus A2}

Growth on maltose or fructose did not eliminate EM pathway activity in strain GFI (Fig. $2 b, 3 b$ ), although cumulative $\mathrm{C}-1$ and $\mathrm{C}-4$ release from glucose considerably exceeded 

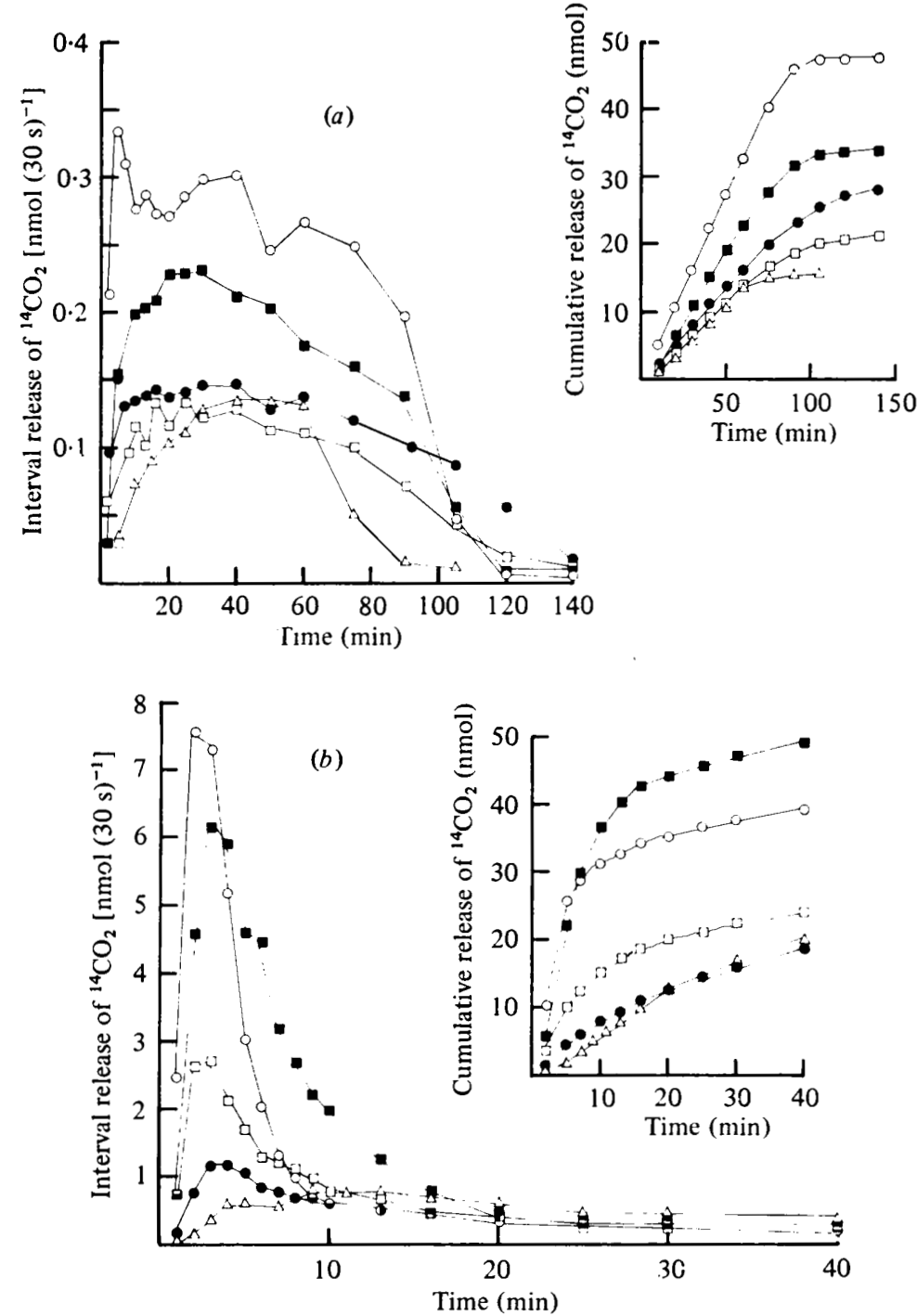

Fig. 3. Radiorespirometry of specifically labelled $\left[{ }^{14} \mathrm{C}\right]$ glucoses by Thiobacillus $\mathrm{A} 2$ grown on fructose: (a) wild-type ( $4.5 \mathrm{mg}$ dry wt) and $(b)$ strain GFI (4.13 mg dry wt). Release of ${ }^{14} \mathrm{CO}_{2}$ from glucose labelled in C-1 $(O), \mathbf{C}-2(O), C-3(\square), C-4(\square)$ and $C-6(\Delta)$ is expressed as interval release and (insets) cunulative release from $66.6 \mathrm{nmol}$ glucose.

that of C-3 (Table 4). It is likely that the triple-pathway calculation (Wood et al., 1977) thus overestimated the EM pathway contribution to glucose oxidation (Table 4). After growth on arabinose, both the wild-type and GFI strains lost EM pathway activity (Fig. 4). The glucose oxidation rate by GFI was 13.8 ( \pm s.D. 2.9$) \mathrm{nmol} \mathrm{CO}_{2} \mathrm{~min}^{-1}$ (mg dry wt) $)^{-1}$ (from nine determinations using glucose-grown cultures), but was depressed after growth on arabinose or fructose (Table 4).

In agreement with the radiorespirometric assays, GFI grown on maltose or fructose contained very high activities of phosphofructokinase and low activities of the key ED pathway enzymes (Table 5), while organisms grown on arabinose lacked phosphofructokinase, but had higher activities of 6-PG dehydratase, KDPG aldolase and phosphoketolase than those grown on maltose or fructose (Table 5). 
Table 2. Contributions of the Embden-Meyerhof, Entner-Doudoroff and pentose phosphate pathways to glucose oxidation by Thiobacillus A2 after growth on various sugars

Results were calculated from the final cumulative data of Table 1 using the equation for ED + PP pathway combinations (see text) except for the first two glucose cultures, where the three-pathway calculation (Wood et al., 1977) was used.

Growth substrate

Glucose (sucrose inoculum)

Glucose (thiosulphate inoculum)

Maltose
Glucose+Maltose
Sucrose
Fructose
Galactose
Mannose
Melezitose
Arabinose
Ribose
Xylose

Relative contribution (\%) of pathways

$\begin{array}{ccc}\begin{array}{c}\text { Embden- } \\ \text { Meyerhof }\end{array} & \begin{array}{c}\text { Entner- } \\ \text { Doudoroff }\end{array} & \begin{array}{c}\text { Pentose } \\ \text { phosphate }\end{array} \\ 56 & 28 & 16 \\ \text { (1) } 38 & 13(87)^{*} & 49(13)^{*} \\ \text { (2) } 0 & 79 & 21 \\ 0 & 84 & 16 \\ 0 & 81 & 19 \\ 0 & 68 & 32 \\ 0 & 77 & 23 \\ 0 & 77 & 23 \\ 0 & 82 & 18 \\ 0 & 68 & 32 \\ 0 & 90 & 10 \\ 0 & 86 & 14 \\ 0 & 78 & 22\end{array}$

* Values in parentheses are proportions indicated by the two-pathway equation assuming the absence of the EM pathway.

Table 3. Enzymes of carbohydrate metabolism in Thiobacillus A2 grown on various sugars Activity [nmol $\left.\min ^{-1}(\mathrm{mg} \text { protein })^{-1}\right]$

\begin{tabular}{|c|c|c|c|c|c|c|c|}
\hline Growth substrate $\ldots$ & Glucose* & Glucose $\dagger$ & Sucrose & Fructose & Arabinose & Maltose & $\begin{array}{c}\text { Glucose }+ \\
\text { Maltose }\end{array}$ \\
\hline \multicolumn{8}{|l|}{ Enzyme } \\
\hline $\begin{array}{l}\text { 6-Phospho- } \\
\text { fructokinase }\end{array}$ & $0-3 \cdot 0$ & $27(53) \ddagger$ & ND & ND & $0-4 \cdot 0$ & ND & ND \\
\hline $\begin{array}{l}\text { Glucosephosphate } \\
\text { isomerase }\end{array}$ & 一 & $-(439)$ & 一 & $-(332)$ & 一 & 537 & - \\
\hline $\begin{array}{l}\text { Fructose-1,6-bis- } \\
\text { phosphate aldolase }\end{array}$ & 19 & $-(20)$ & 一 (15) & - (9) & 一 & $-(18)$ & 一 \\
\hline $\begin{array}{l}\text { 6-Phosphogluconate } \\
\text { dehydratase + KDPG } \\
\text { aldolase }\end{array}$ & 4-9 & $32(30)$ & $55(35)$ & - (41) & $1 \cdot 1-8 \cdot 0$ & $88(35)$ & 70 \\
\hline KDPG aldolase & 31 & 89 & 215 & 一 & 25 & 185 & 185 \\
\hline Phosphoketolase & $1 \cdot 7$ & $5 \cdot 7$ & $2 \cdot 2$ & $3 \cdot 9$ & $1 \cdot 4$ & $3 \cdot 0$ & 3.4 \\
\hline
\end{tabular}

ND, Not detectable; 一, not determined.

* Thiosulphate-grown inoculum (these organisms gave the radiorespirometry pattern seen in Fig. $1 b$ ).

+ Sucrose-grown inoculum (see also Fig. 1a).

$\ddagger$ Figures in parentheses are comparative data from Wood et al. (1977).

Oxidation of $\left[1-{ }^{14} \mathrm{C}\right]$ fructose and $\left[\mathrm{U}-{ }^{14} \mathrm{C}\right]$ fructose by fructose-grown $\mathrm{GFI}$ was compared with glucose oxidation. Fructose was oxidized at a rate of $7.45 \mathrm{nmol} \mathrm{CO}_{2} \mathrm{~min}^{-1}(\mathrm{mg}$ dry wt) $)^{-1}$, and about $52 \%$ and $47 \%$ of $\mathrm{C}-1$ and $\mathrm{C}-\mathrm{U}$, respectively, of $33.3 \mu \mathrm{M}$-fructose was converted to $\mathrm{CO}_{2}$ under the standard radiorespirometry assay conditions. This compared with $60 \%$ and $53 \%$ of the C-1 and C-U of glucose, possibly indicating somewhat greater EM pathway activity during fructose than glucose oxidation.

Sucrose oxidation by Thiobacillus A2 grown on different sugars

The initial rates of $\left[\mathrm{U}-{ }^{14} \mathrm{C}\right]$ sucrose oxidation by bacteria previously grown on sucrose, maltose, glucose or fructose were, respectively, $2.3,1.7,0.5$ and $0.03 \mathrm{nmol} \mathrm{CO}_{2} \mathrm{~min}^{-1}$ 


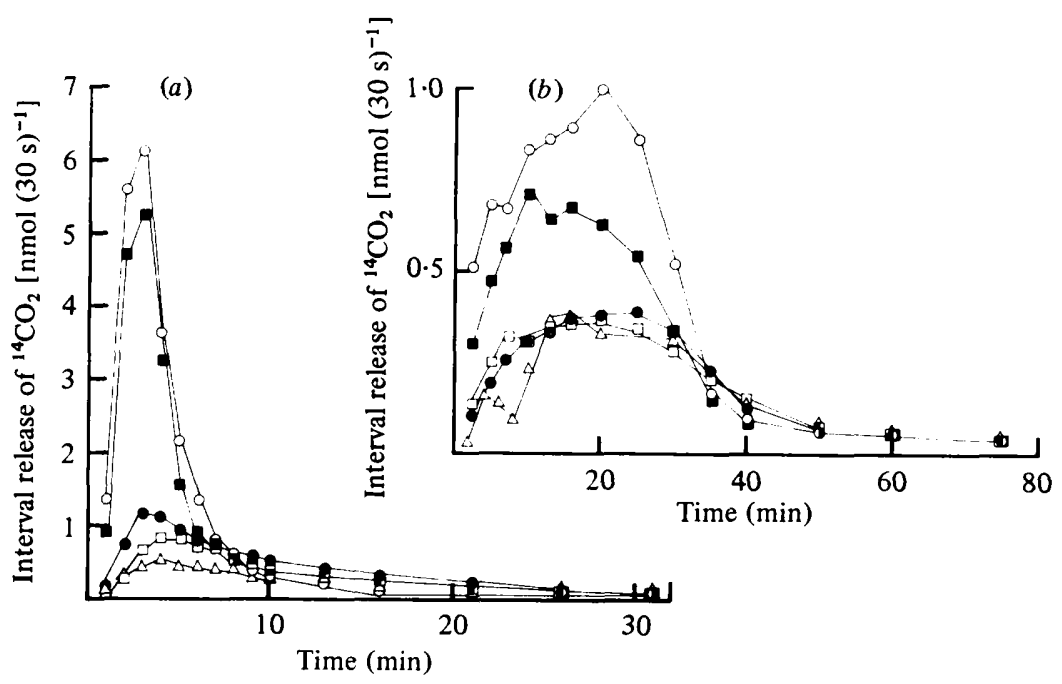

Fig. 4. Radiorespirometry of specifically labelled $\left.{ }^{14} \mathrm{C}\right]$ glucoses by Thiobacillus $\mathrm{A} 2$ grown on arabinose: (a) wild-type $\left(1.75 \mathrm{mg}\right.$ dry wt) and $(b)$ strain GFI $\left(1.75 \mathrm{mg}\right.$ dry wt). Release of ${ }^{14} \mathrm{CO}_{2}$ from glucose labelled in $\mathrm{C}-1(0), \mathrm{C}-2(\bullet), \mathrm{C}-3(\square), \mathrm{C}-4(\square)$ and $\mathrm{C}-6(\Delta)$ is expressed as interval release from $66 \cdot 6 \mathrm{nmol}$ glucose.

Table 4. Glucose radiorespirometry by Thiobacillus A2 strain GFI grown on maltose, fructose or arabinose

Amount of organism used Incubation

Growth substrate (concn, mM)

Maltose (10)

Fructose (20)

Arabinose (24)

$$
\begin{array}{cc}
\text { [mg dry wt } & \text { time } \\
\left.(2 \mathrm{ml})^{-1}\right] & (\mathrm{min})
\end{array}
$$

$1 \cdot 80$

$4 \cdot 13$

$1 \cdot 75$

\begin{tabular}{|c|c|c|c|c|}
\hline \multicolumn{5}{|c|}{$\begin{array}{c}{ }^{14} \mathrm{CO}_{2} \text { release } \\
\text { (nmol, from } 66 \cdot 6 \text { nmol glucose) }\end{array}$} \\
\hline C-1 & C-2 & C-3 & C-4 & C-6 \\
\hline $47 \cdot 9$ & $24 \cdot 0$ & $23 \cdot 2$ & 34.9 & 1 \\
\hline $43 \cdot 8$ & $25 \cdot 8$ & $29 \cdot 7$ & $54 \cdot 2$ & $26 \cdot 7$ \\
\hline $50 \cdot 5$ & $24 \cdot 8$ & $25 \cdot 3$ & $37 \cdot 2$ & $22 \cdot 7$ \\
\hline
\end{tabular}

31
90

90

75
Rate of oxidation of [U- $\left.{ }^{14} \mathrm{C}\right]-$ glucose*

* Expressed as $\mathrm{nmol}{ }^{14} \mathrm{CO}_{2} \min ^{-1}(\mathrm{mg} \text { dry } w t)^{-1}$.

\begin{tabular}{|c|c|c|c|}
\hline \multirow[b]{2}{*}{ Enzyme } & \multicolumn{3}{|c|}{ Activity $\left.\left[\mathrm{nmol} \mathrm{min} \mathrm{m}^{-1} \text { (mg protein }\right)^{-1}\right]$} \\
\hline & Maltose & Fructose & Arabinose \\
\hline 6-Phosphofructokinase & 175 & 332 & ND \\
\hline phosphate isomerase & 739 & - & - \\
\hline 6-Phosphogluconate dehydratase + KDPG aldolase & $6 \cdot 1$ & $6 \cdot 8$ & $8 \cdot 8$ \\
\hline KDPG aldolase & $4 \cdot 7$ & 8.7 & $49 \cdot 0$ \\
\hline Phosphoketolase & $1 \cdot 7$ & $2 \cdot 4$ & 7.5 \\
\hline
\end{tabular}

\begin{tabular}{lccc} 
Growth substrate & \multicolumn{2}{c}{ Relative contribution (\%) of pathways } \\
\cline { 2 - 4 } $\begin{array}{c}\text { Embden- } \\
\text { Meyerhof }\end{array}$ & $\begin{array}{c}\text { Entner- } \\
\text { Doudoroff }\end{array}$ & $\begin{array}{c}\text { Pentose } \\
\text { phosphate }\end{array}$ \\
Maltose & 33 & 17 & 50 \\
Fructose & 40 & 33 & 26 \\
Arabinose & 0 & 80 & 20
\end{tabular}

Table 5. Enzymes of carbohydrate metabolism in Thiobacillus A2 strain GFI grown on various sugars

ND, Not detectable; 一, not determined. 


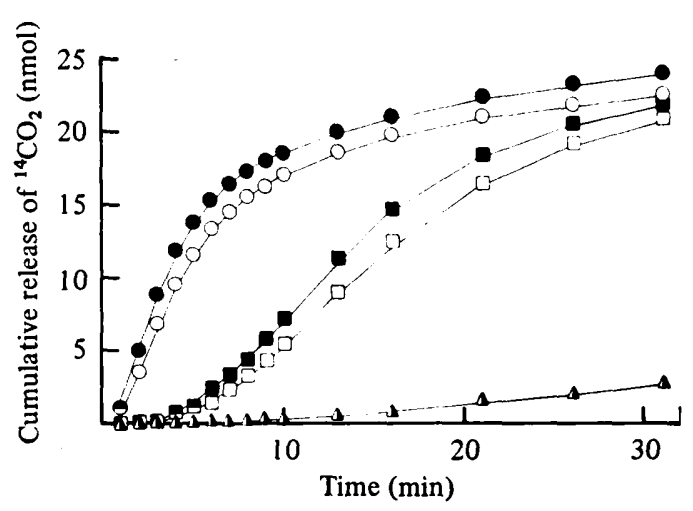

Fig. 5. Radiorespirometry of specifically labelled [ $\left.{ }^{14} \mathrm{C}\right]$ sucroses by Thiobacillus $\mathrm{A} 2$ grown on sucrose $(O, O ; 1.73 \mathrm{mg}$ dry wt) or glucose $(\square, \square ; 1.76 \mathrm{mg}$ dry wt) or fructose $(\Delta, \Delta ; 1.68 \mathrm{mg}$ dry wt). Cumulative release of ${ }^{14} \mathrm{CO}_{2}$ from $66 \mathrm{nmol}$ sucrose universally labelled with ${ }^{14} \mathrm{C}$ in either the glucose residue $(O, \square, \Delta)$ or the fructose residue $(0, \square, \Delta)$ is shown.

(mg dry wt) ${ }^{-1}$. Sucrose-grown Thiobacillus A2 oxidized both the glucose and fructose components of sucrose at similar rates, but $\mathrm{CO}_{2}$ production was slightly greater from the fructose half of the molecule (Fig. 5). Virtually identical kinetics were observed with maltosegrown organisms. Oxidation by glucose-grown organisms showed a lag and acceleration phase lasting about $6 \mathrm{~min}$ (Fig. 5), but $\mathrm{CO}_{2}$ production from the fructose residue slightly exceeded that from the glucose residue throughout (Fig. 5). Similarly, no great discrimination could be detected during the very slow oxidation effected by fructose-grown Thiobacillus A2 (Fig. 5).

Radiorespirometric competition experiments to demonstrate the predominant roles of the ED and PP pathways in glucose and pentose metabolism by Thiobacillus A2 grown on maltose or arabinose

If maltose-grown Thiobacillus A2 does not use the EM pathway (Table 2), release of $\mathrm{CO}_{2}$ from the C-3 of glucose would be depressed by gluconate as severely as that from $\mathrm{C}-1$ and $\mathrm{C}-4$. The rates and amounts of C-1, C-3 and C-4 release were all inhibited by gluconate, in agreement with release of these by the ED and PP pathways (Fig. 6).

If arabinose metabolism depends on initial production of glucose 6-phosphate by the reactions of the PP pathway (Krebs \& Kornberg, 1957), rather than scission by phosphoketolase after conversion to xylulose 5-phosphate, addition of arabinose to arabinosegrown Thiobacillus A2 oxidizing glucose would similarly depress $\mathrm{CO}_{2}$ release from $\mathrm{C}-1$, $\mathrm{C}-2, \mathrm{C}-3$ and C-4. This effect was observed, $1 \mathrm{~mm}$-arabinose decreasing cumulative release of $\mathrm{CO}_{2}$ from all four by 80 to $90 \%$ (Fig. 7).

Similarly, if glucose 6-phosphate is an intermediate in arabinose metabolism, addition of glucose or an equimolar amount of extra arabinose to arabinose-grown Thiobacillus A2 oxidizing $\left[1{ }^{14} \mathrm{C}\right]$ arabinose would be expected to inhibit the rate of ${ }^{14} \mathrm{CO}_{2}$ release to an equivalent extent. Glucose and extra arabinose had exactly this predicted effect (Fig. 8).

Since, by the operation of the PP pathway, C-2 of glucose and C-1 of pentose become the $\mathrm{C}-1$ of glucose 6-phosphate, some similarity of behaviour would be expected between the metabolism of $\mathrm{C}-1$ and, especially, $\mathrm{C}-2$ of glucose and of $\mathrm{C}-1$ of pentoses. Using arabinoseand ribose-grown Thiobacillus $\mathrm{A} 2$, such a general similarity in extent of ${ }^{14} \mathrm{CO}_{2}$ release was established (Table 6). 


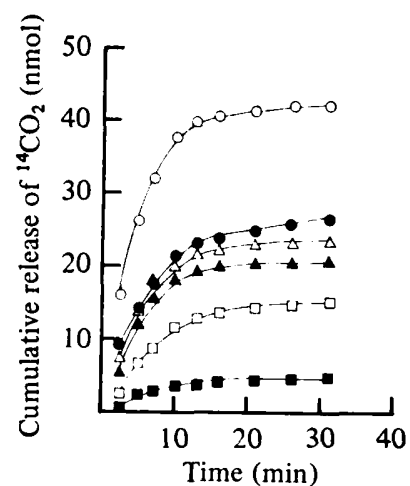

Fig. 6

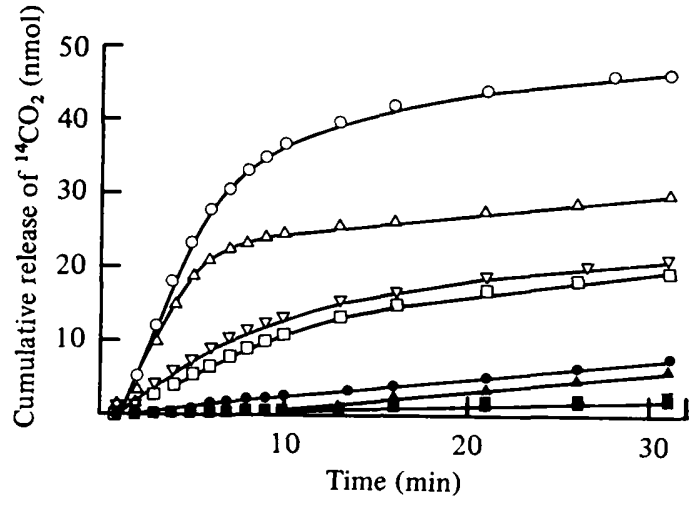

Fig. 7

Fig. 6. Effect of gluconate on glucose radiorespirometry of Thiobacillus A2 (1.73 mg dry wt) previously grown on maltose. Cumulative release of ${ }^{14} \mathrm{CO}_{2}$ in the absence (open symbols) and presence (solid symbols) of 1 mm-potassium gluconate is shown from 66.6 nmol glucose labelled in $\mathrm{C}-1(\mathrm{O}, \mathrm{O}), \mathrm{C}-3(\square, \square)$ and $\mathrm{C}-4(\triangle, \Delta)$.

Fig. 7. Effect of arabinose on glucose radiorespirometry of Thiobacillus A2 (1.76 mg dry wt) previously grown on arabinose. Cumulative release of ${ }^{14} \mathrm{CO}_{2}$ in the absence (open symbols) and presence (solid symbols) of $1 \mathrm{~mm}$-arabinose is shown from $66.6 \mathrm{nmol}$ glucose labelled in $\mathrm{C}-1(\mathrm{O}, \mathrm{O})$, $\mathrm{C}-2(\nabla, \nabla), \mathrm{C}-3(\square, \square)$ and $\mathrm{C}-4(\Delta, \Delta)$.

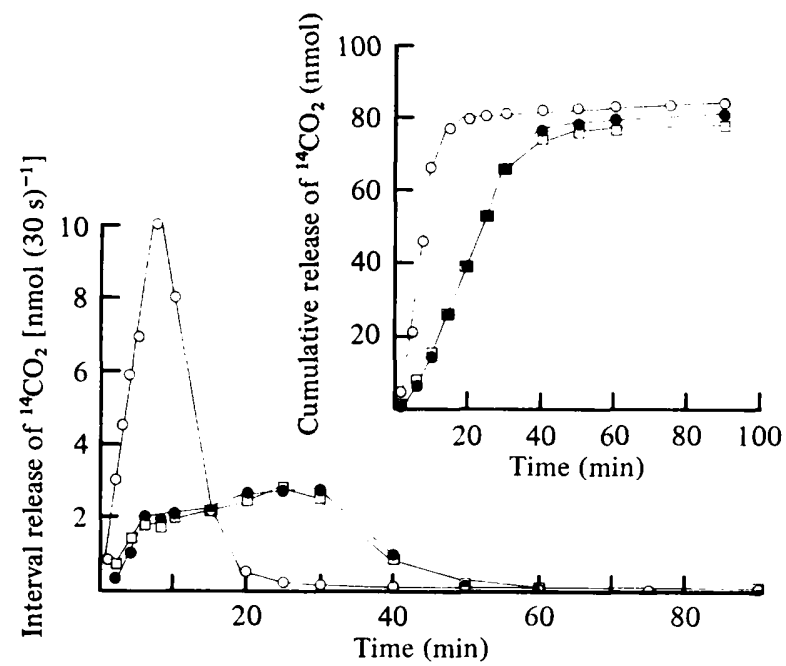

Fig. 8. Effect of glucose and extra arabinose on ${ }^{14} \mathrm{CO}_{2}$ release from $\left[1-{ }^{14} \mathrm{C}\right]$ arabinose by Thiobacillus A2 (1.75 mg dry wt) previously grown on arabinose. ${ }^{14} \mathrm{CO}_{2}$ production from $100 \mathrm{nmol}$ $\left[1-{ }^{14} \mathrm{C}\right.$ ]arabinose was measured in the absence $(O)$ or presence of $400 \mathrm{nmol}$ unlabelled glucose $(\square)$ or $400 \mathrm{nmol}$ additional unlabelled arabinose (O). ${ }^{14} \mathrm{CO}_{2}$ release is expressed as interval release $\left[\mathrm{nmol}(30 \mathrm{~s})^{-1}\right]$ and (inset) cumulative release.

\section{DISCUSSION}

Earlier views that the central pathways in micro-organisms for the degradation of carbohydrates were relatively invariable in activity, usually with a major and a minor pathway functioning (Wang et al., 1958, 1959; Stern et al., 1960; Goldman \& Blumenthal, 1963; Zagallo \& Wang, 1967; Kersters \& De Ley, 1968; Höfer et al., 1971), and that the EM pathway was characteristically absent from pseudomonads (Tiwari \& Campbell, 1969; Lynch et al., 1975) have been proved by more recent studies to be oversimplifications. The 
Table 6. Oxidation and assimilation of glucose and pentoses by Thiobacillus A2

\begin{tabular}{|c|c|c|c|c|c|c|}
\hline \multirow[b]{3}{*}{$\begin{array}{l}\text { Thiobacillus } \\
\text { A2 strain } \\
\text { (mg dry wt/assay) }\end{array}$} & \multirow[b]{3}{*}{$\begin{array}{l}\text { Growth } \\
\text { substrate }\end{array}$} & \multirow{3}{*}{ 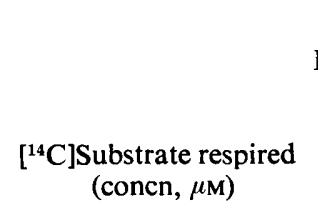 } & \multirow{3}{*}{$\begin{array}{l}\text { Incubation } \\
\text { time for } \\
\text { complete } \\
\text { reaction } \\
\text { (min) }\end{array}$} & \multicolumn{3}{|c|}{ Distribution of recovered ${ }^{14} \mathrm{C}(\%)$} \\
\hline & & & & \multirow[b]{2}{*}{${ }^{14} \mathrm{CO}_{2}$} & \multicolumn{2}{|c|}{ Non-volatile ${ }^{14} \mathrm{C}$} \\
\hline & & & & & Total & $\begin{array}{l}\text { Assimilated } \\
\text { into cells }\end{array}$ \\
\hline Wild-type (1.75) & Arabinose & $\begin{array}{l}{\left[1^{14} \mathrm{C}\right] \text { Arabinose }(50)} \\
{\left[1-^{14} \mathrm{C}\right] \text { Arabinose }(250)} \\
{\left[11^{14} \mathrm{C}\right] \text { Glucose }(33)} \\
{\left[2{ }^{14} \mathrm{C}\right] \text { Glucose }(34)}\end{array}$ & $\begin{array}{l}90 \\
90 \\
31 \\
31\end{array}$ & $\begin{array}{l}82 \cdot 2 \\
81 \cdot 7 \\
79 \cdot 9 \\
42 \cdot 2\end{array}$ & $\begin{array}{l}17 \cdot 8 \\
18 \cdot 3 \\
20 \cdot 1 \\
57 \cdot 8\end{array}$ & $\begin{array}{l}11 \cdot 1 \\
- \\
-\end{array}$ \\
\hline GFI (1.75) & Arabinose & $\begin{array}{l}{\left[1-^{14} \mathrm{C}\right] \text { Arabinose }(50)} \\
{\left[1-^{14} \mathrm{C}\right] \text { Glucose }(30)} \\
{\left[2-^{-14} \mathrm{C}\right] \text { Glucose }(34)}\end{array}$ & $\begin{array}{l}75 \\
75 \\
75\end{array}$ & $\begin{array}{l}56 \cdot 5 \\
68 \cdot 0 \\
38 \cdot 3\end{array}$ & $\begin{array}{l}43 \cdot 5 \\
32 \cdot 0 \\
61 \cdot 7\end{array}$ & $\frac{32 \cdot 0}{47 \cdot 0}$ \\
\hline Wild-type (8.75) & Arabinose & {$\left[1{ }^{14} \mathrm{C}\right]$ Ribose (33) } & 180 & $53 \cdot 6$ & $46 \cdot 4$ & $44 \cdot 0$ \\
\hline Wild-type (11-25) & Ribose & $\begin{array}{l}{\left[1--^{14} \mathrm{C}\right] \text { Ribose (33) }} \\
{\left[1--^{14} \mathrm{C}\right] \text { Glucose }(33)} \\
{\left[2-{ }^{14} \mathrm{C}\right] \text { Glucose }(34)}\end{array}$ & $\begin{array}{r}150 \\
75 \\
95\end{array}$ & $\begin{array}{l}31 \cdot 5 \\
74 \cdot 4 \\
36 \cdot 6\end{array}$ & $\begin{array}{l}68 \cdot 5 \\
25 \cdot 6 \\
63 \cdot 4\end{array}$ & $\begin{array}{l}- \\
-\end{array}$ \\
\hline Wild-type $(1 \cdot 8)$ & Xylose & $\begin{array}{l}{\left[1{ }^{14} \mathrm{C}\right] \text { Glucose }(33)} \\
{\left[2-{ }^{14} \mathrm{C}\right] \text { Glucose }(34)}\end{array}$ & $\begin{array}{l}31 \\
31\end{array}$ & $\begin{array}{l}90 \cdot 2 \\
36 \cdot 4\end{array}$ & $\begin{array}{r}9 \cdot 8 \\
63 \cdot 6\end{array}$ & - \\
\hline Wild-type (1.75) & Glucose & $\begin{array}{l}{\left[1-^{14} \mathrm{C}\right] \text { Arabinose (40) }} \\
{\left[1-^{14} \mathrm{C}\right] \text { Glucose (33) }} \\
{\left[2-^{-14} \mathrm{C}\right] \text { Glucose (34) }}\end{array}$ & $\begin{array}{c}150^{*} \\
31 \\
31\end{array}$ & $\begin{array}{l}75 \cdot 0 \\
80 \cdot 4 \\
48 \cdot 9\end{array}$ & $\begin{array}{l}25 \cdot 0 \\
19 \cdot 6 \\
51 \cdot 1\end{array}$ & - \\
\hline
\end{tabular}

-, Not determined.

* Oxidation rate $0.10 \mathrm{nmol} \mathrm{CO}_{2} \mathrm{~min}^{-1}\left(\mathrm{mg}\right.$ dry wt) ${ }^{-1}$ for first $60 \mathrm{~min}$, accelerating to 0.69 for the period 75 to $105 \mathrm{~min}$.

discovery of fructose 1,6-bisphosphate formation by PEP-dependent phosphorylation of fructose to fructose 1-phosphate (by PEP-fructose phosphotransferase) and 1-phosphofructokinase (1-PFK) in Arthrobacter pyridinolis (Sobel \& Krulwich, 1973) and Pseudomonas doudoroffi (Baumann \& Baumann, 1975) suggested that a modified EM pathway could function in these organisms. Subsequently, van Dijken \& Quayle (1977) and Sawyer et al. (1977) showed these enzymes to function in numerous Pseudomonas species. Using radiolabelling experiments and enzyme-deficient mutants, these workers demonstrated that 1-PFK and an EM pathway could contribute to fructose metabolism, although in most cases the major route for fructose use was the ED pathway. The EM pathway was, however, indicated to be the major pathway for fructose degradation by $P$. extorquens (van Dijken \& Quayle, 1977) and by a 6-PG dehydratase-negative mutant of $P$. putida 90 that could not grow on glucose (Vicente \& Cánovas, 1973; Sawyer et al., 1977). In general, few studies have shown marked variation in the proportionate contributions of multiple pathways during growth on a single substrate. Goldman \& Blumenthal (1964) showed the proportion of glucose oxidized by the EM pathway in Bacillus cereus to increase from 80 to $98 \%$ during differentiation. Considerable variation in PP pathway activity could be induced in batch and chemostat cultures of Gluconobacter oxydans (Olijve \& Kok, 1979 $a, b$ ). Several organisms, including Microcyclus (Raj, 1977), Escherichia coli (Eisenberg \& Dobrogosz, 1967) and Thiobacillus A2 (Wood et al., 1977) are potentially capable of using more than two carbohydrate degradation pathways simultaneously. Considerable variation of the EM, ED and PP pathway proportions could be induced in Thiobacillus A2 simply by varying growth conditions in glucose- or ammonium-limited chemostats (Wood \& Kelly, 1979). In Microcyclus flavus, glucose was used almost exclusively by the EM pathway (Raj, 1977), but the organism showed simultaneous activity of EM, ED and PP pathways when grown on glucose plus gluconate (Raj, 1977). Similarly, gluconate-grown E. coli degraded glucose and gluconate simultaneously and independently by the EM and ED pathways (Eisenberg \& Dobrogosz, 
1967). Different species of Microcyclus used either the EM or the ED pathway as the major $(80 \%)$ route of glucose degradation (Raj, 1977). A remarkable situation was demonstrated by Conrad \& Schlegel (1977) in Rhodopseudomonas capsulata, which degrades glucose by the ED pathway and fructose by the EM pathway by means of the PEP-fructose phosphotransferase and 1-phosphofructokinase system. Van Dijken \& Quayle (1977) drew attention to the energetic advantage of ancillary operation of the EM pathway (to generate PEP) in pseudomonads using the ED pathway, although Wood \& Kelly (1979) previously observed that while the EM pathway is energetically superior to the ED pathway (Wood, 1961), little effect on growth yield results, as most energy conservation accompanies the tricarboxylic acid cycle. Indeed, Bang \& Baumann (1978) believed that the FDP generated by $P$. putida was largely metabolized by the ED pathway after hydrolysis of the 1-phosphate, effectively wasting one ATP molecule per fructose molecule metabolized, and making the pathway to pyruvate one in which two ATP equivalents are consumed and four generated (three during NADH oxidation).

Against this background our current work with Thiobacillus A2 has extended the detailed study of the effect of substrate on pathway selection to an organism exhibiting extraordinarily complex metabolic potential, in which at least three glucose-degrading pathways can operate simultaneously. Because of the complexity of the degradation pathways in Thiobacillus A2 we employed a variety of techniques to confirm the routes actually functioning and studied a wide range of sugars, including pentoses and disaccharides, since different substrates could have emphasized the activity of otherwise minor pathways. For example, it was thought that pentose metabolism might have involved phosphoketolase (Greenley \& Smith, 1979; Wood \& Kelly, 1979). It has also been shown that pentose metabolism in $E$. coli is largely effected by the EM pathway after synthesis of hexose from the added pentoses (Mahler \& Cordes, 1966).

A number of conclusions can be drawn about the wild-type Thiobacillus A2. The EM, ED and PP pathways only operate simultaneously in organisms grown on glucose and even this is variable, depending on prior growth conditions. Generally, the ED is the predominant pathway during growth on hexoses, disaccharides and melezitose, with some PP pathway activity. In contrast to $R$. capsulata (Conrad \& Schlegel, 1977), wild-type Thiobacillus A2 grown on fructose did not exhibit significant EM pathway activity. This is consistent with the probable absence of 1-PFK from Thiobacillus A2 (Wood et al., 1977) and the absence of 6-PFK from fructose-grown bacteria (Table 3). Significant KDPG aldolase activity was present in all cultures, including those grown on glucose and estimated to use the EM pathway as the major route (Tables 2 and 3). This is consistent with KDPG aldolase being present at a high basal, or constitutive activity, possibly in response to induction by endogenous gluconate (e.g. from the PP pathway) as shown for E. coli and P. fluorescens (Eisenberg \& Dobrogosz, 1967; Quay et al., 1972). Surprisingly, activities of 6-PG dehydratase and KDPG aldolase were low in arabinose-grown bacteria (Table 3), even though these appeared to use glucose mainly by the ED pathway (Table 2; Fig. $4 a$ ). The low phosphoketolase activity in all the cultures, including those grown on arabinose (Table 3), indicated that pentose metabolism occurred predominantly by hexose phosphate synthesis by the PP pathway. The occurrence of glucose as an obligatory intermediate in arabinose oxidation was supported by the 80 to $90 \%$ depression by arabinose of the rate of release of C-1, C-2, C-3 and C-4 of glucose by arabinose-grown organisms (Fig. 7), and the equal depression of C-1 release from $\left[1-{ }^{14} \mathrm{C}\right]$ arabinose by additional unlabelled arabinose or glucose (Fig. 8).

Behaviour of the fast-growing GFI strain was similar after growth on arabinose to that of the wild-type. Pentose metabolism in both strains thus proceeded via hexose, that behaved metabolically like hexose supplied as fructose, galactose, mannose, or derived from disaccharide, xylose or ribose metabolism (Table 2). In contrast, strain GFI grown on maltose or fructose used the triple-pathway system for oxidizing glucose and contained very 
high activities of 6-PFK but low KDPG aldolase (Tables 4 and 5 ; Fig. $2 b, 3 b$ ). In spite of this, the proportion of glucose passing through the ED pathway was at least as high as that shown in Table 4 (cf. Fig. $2 b, 3 b$ ). Relative regulation of the EM and ED pathways in Thiobacillus A2 wild-type and GFI strains cannot be unequivocally explained, since the key ED pathway enzymes were always detectable. This contrasts with E. coli, Serratia and Salmonella (Eisenberg \& Dobrogosz, 1967) in which 6-PG dehydratase was absent from glucose-grown organisms even though KDPG aldolase was present. 6-PFK was clearly the regulatory locus for repression of the EM pathway in most of our cultures, but the biochemical regulator is not at present identifiable. It is puzzling that the wild-type grown on maltose, with or without glucose, lacked EM pathway activity while strain GFI retained high activity. We propose that glucose transport or phosphorylation is different in the two strains (resulting in different response to altering growth conditions: Wood \& Kelly, 1979), leading to different concentrations of intracellular glucose or glucose 6-phosphate, which may be of regulatory importance. Intracellular levels of key regulatory compounds are presumably unique in growth of the wild-type on glucose and sufficiently different in wildtype and GFI strains on other sugars to produce (i) repression of key enzymes (such as 6-PFK) or (ii) regulation of the flow of intermediates into the different pathways dependent on $K_{\mathrm{m}}$ values of branch point or key enzymes (such as 6-PG dehydratase, 6-PG dehydrogenase, glucosephosphate isomerase, FDP aldolase and KDPG aldolase).

The experiments with disaccharides and melezitose do not enable explanation of their stimulation of the slow growth rate of the wild-type on glucose, but do serve to suggest that sucrose uptake or hydrolysis is severely depressed by growth on fructose but much less so by glucose (Fig. 5). Marginally more rapid oxidation of the fructose moiety of sucrose could reflect more rapid direct phosphorylation of fructose than glucose but does not suggest anything unusual in the mechanism of disaccharide metabolism.

In conclusion, Thiobacillus A2 exhibits regulatory changes in its sugar metabolism in response to growth substrate that are similar to those seen with some Pseudomonas species but also to some seen in enterobacteria and Microcyclus. Its behaviour would thus seem to be determined by a unique mixture of regulatory functions different from those so far found in other bacteria.

We thank the Science Research Council for grants in aid of this work, Professor J. R. Quayle for a gift of barium KDPG, Dr C. H. Wang for a gift of $\left[3-{ }^{14} \mathrm{C}\right]$ glucose and Dr C. F. Thurston for stimulating discussions.

\section{REFERENCES}

Bang, S. S. \& Baumann, P. (1978). Properties of fructose-1,6-diphosphate phosphatase and fructose-1,6-diphosphate aldolase from Pseudomonas putida. Current Microbiology 1, 5-9.

Baumann, L. \& BaumanN, P. (1975). Catabolism of D-fructose and D-ribose by Pseudomonas doudoroffi. Archives of Microbiology 105, 225-248.

Conrad, R. \& Schlegel, H. G. (1977). Different degradation pathways for glucose and fructose in Rhcdopseudcmonas capsulata. Archives of Microbiology 112, 39-48.

Eisenberg, R. C. \& Dobrogosz, W. J. (1967). Gluconate metabolism in Escherichia coli. Journal of Bacteriology 93, 941-949.

Goldman, M. \& Blumenthal, H. J. (1963). Pathways of glucose catabolism in Bacillus subtilis. Journal of Bacteriology 86, 303-311.

Goldman, M. \& Blumenthal, H. J. (1964).
Pathways of glucose catabolism in Bacillus cereus. Journal of Bacteriology 87, 377-386.

Goldberg, M., Fessenden, J. M. \& Racker, E. (1966). Phosphoketolase. Methods in Enzymology 9, 515-520.

Greenley, D. E. \& Smith, D. W. (1979). A novel pathway of glucose catabolism in Thicbacillus novellus. Archives of Micrcbiology 122, 257-261.

Höfer, M., Brand, K., DECKNer, K. \& BeCKer, J.-U. (1971). Importance of the pentose phosphate pathway for D-glucose catabolism in the obligatory aerobic yeast Rhodotorula gracilis. Biochemical Journal 123, 855-863.

Johnson, E. J. \& MACElroy, R. D. (1973). Regulation in the chemolithotroph Thicbacillus neapolitanus: fructose-1,6-diphosphatase. Archives of Microbiology 93, 23-28.

Kersters, K. \& De Ley, J. (1968). The occurrence 
of the Entner-Doudoroff pathway in bacteria. Antonie van Leeuwenhoek 34, 393-408.

KREBS, H. A. \& Kornberg, A. (1957). Energy transformations in living matter. Ergebnisse der Physiologie (biologischen Chemie und experimentellen Pharmakologie) 49, 212-298.

LYNCH, W. H., MacLeOd, J. \& Franklin, M. (1975). Effect of temperature on the activity and synthesis of glucose-catabolizing enzymes in Pseudomonas fluorescens. Canadian Journal of Microbiology 21, 1560-1572.

MAHLER, H. R. \& CoRdes, E. H. (1966). Biological Chemistry, pp. 454-455. New York: Harper \& Row.

OliJVE, W. \& KoK, J. J. (1979a). Analysis of growth of Gluconobacter oxydans in glucose containing media. Archives if Microbiology 121, 283-290.

OliJVE, W. \& KoK, J. J. (1979b). An analysis of the growth of Gluconobacter oxydans in chemostat cultures. Archives of Microbiology 121, 291-297.

ORNSTON, L. N. (1971). Regulation of catabolic pathways in Pseudomonas. Bacteriological Reviews 35, 87-116.

Quay, S. C., Friedman, S. B. \& Eisenberg, R. C. (1972). Gluconate regulation of glucose catabolism in Pseudomonas fluorescens. Journal of Bacteriology 112, 291-298.

RAJ, H. D. (1977). Microcyclus and related ringforming bacteria. CRC Critical Reviews in Microbiology 4, 243-268.

Sawyer, M. H., BaumanN, P., Baumann, L., Berman, S. M., Cánovas, J. L. \& Berman, R. H. (1977). Pathways of D-fructose catabolism in species of Pseudomonas. Archives of Microbiology 112, 49-55.

Smith, A. L., Kelly, D. P. \& Wood, A. P. (1980). Metabolism of Thiobacillus A2 grown under autotrophic, mixotrophic and heterotrophic conditions in chemostat culture. Journal of General Microbiology 121 (in the Press).

Sobel, M. E. \& KRULwich, T. A. (1973).Metabolism of D-fructose by Arthrobacter pyridinolis. Journal of Bacteriology 113, 907-913.

Stern, I. J., WANG, C. H. \& Gilmour, C. M. (1960). Comparative metabolism of carbohydrates in Pseudomonas species. Journal of Bacteriology 79, 601-611.

TAYLOR, B. F. \& HoARE, D. S. (1969). New facultative Thiobacillus and a reevaluation of the heterotrophic potential of Thiobacillus novellus. Journal of Bactericlogy 100, 487-497.
Tiwari, N. P. \& Campbell, J. J. R. (1969). Enzymatic control of the metabolic activity of Pseudomonas aeruginosa growing in glucose or succinate media. Biochimica et biophysica acta 192, 395-401.

VAN DiJKen, J. P. \& QuaYle, J. R. (1977). Fructose metabolism in four Pseudomonas species. Archives of Microbiology 114, 281-286.

Vicente, M. \& CÁNOVAS, J. L. (1973). Glucolysis in Pseudomonas putida: physiological role of alternative routes from the analysis of defective mutants. Journal of Bacteriology 116, 908-914.

Wang, C. H., Stern, I., Gilmour, C. M., KLUNGSoyr, S., ReED, D. J., Bialy, J. J., Christensen, B. E. \& Cheldelin, V. H. (1958). Comparative study of glucose catabolism by the radiorespirometric method. Journal of Bacteriology 76, 207216.

WANG, C. H., Stern, I. J. \& Gilmour, C. M. (1959). The catabolism of glucose and gluconate in Pseudomonas species. Archives of Biochemistry and Biophysics 81, 489-492.

WooD, W. A. (1961). Fermentation of carbohydrates and related compounds. In The Bacteria, vol. 2, pp. 59-149. Edited by I. C. Gunsalus \& R. Y. Stanier. New York \& London: Academic Press.

Wood, A. P. \& Kelly, D. P. (1977). Heterotrophic growth of Thiobacillus A2 on sugars and organic acids. Archives of Microbiology 113, 257-264.

Wood, A. P. \& Kelly, D. P. (1978). Triple catabolic pathways for glucose in a fast-growing strain of Thiobacillus A2. Archives of Microbiology 117, 309-310.

Wood, A. P. \& Kelly, D. P. (1979). Glucose catabolism in Thiobacillus A2 grown in chemostat culture under carbon or nitrogen limitation. Archives of Microbiology 122, 307-312.

Wood, A. P. \& KelLy, D. P. (1980). Regulation of glucose catabolism in Thiobacillus A2 grown in the chemostat under dual limitation by succinate and glucose. Archives of Microbiology (in the Press).

Wood, A. P., Kelly, D. P. \& Thurston, C. F. (1977). Simultaneous operation of three catabolic pathways in the metabolism of glucose by Thiobacillus A2. Archives of Microbiology 113, 265-274.

ZaGallo, A. C. \& WANG, C. H. (1967). Comparative glucose catabolism of Xanthomonas species. Journal of Bacteriology 93, 970-975. 